Original Research

\title{
Removal of Pollutants by Different Constructed Rapid Infiltration and Change in Surface Characteristics of Fillers
}

\author{
Chao Zhang ${ }^{1}$, Guozhen Zhang, ${ }^{1,2 *}$, Wenwen Yan ${ }^{1}$, Fuping Wu ${ }^{1}$, Tianhong Zhou ${ }^{1}$ \\ ${ }^{1}$ School of Environmental and Municipal Engineering, Lanzhou Jiaotong University, Lanzhou 730070, Gansu, China \\ ${ }^{2}$ Engineering Research Center for Comprehensive Utilization of Water Resource in Cold \\ and Arid Regions of Ministry of Education, Lanzhou 730070, Gansu, China
}

Received: 22 May 2020

Accepted: 16 July 2020

\begin{abstract}
This study was aimed to explore the removal of pollutants by different constructed rapid infiltration (CRI) and change in surface characteristics of fillers. The result showed that the increase of filler height and mechanical ventilation was beneficial to the removal of COD by CRI, but not to the removal of SS; the increase of filler height was beneficial to the removal of most heavy metals, and the effect of mechanical ventilation on the removal of heavy metals was very small. Found by SEM, the biofilm on CRI fillers decreased gradually along the direction of water flow, mechanical ventilation increased the biofilm on CRI filler at $0.8 \mathrm{~m}$, but decreased the biofilm on CRI filler at $1.3 \mathrm{~m}$. Found by the element analysis of EDS, the main elements on the surface of three groups of CRI filler were $\mathrm{O}, \mathrm{C}$ and $\mathrm{Ca}$, in addition, $\mathrm{P}, \mathrm{S}, \mathrm{Cl}, \mathrm{As}, \mathrm{Cd}$ and $\mathrm{Hg}$ were also included; the composition of elements on the surface of three groups of CRI fillers changed little along the direction of water flow, but the proportion of elements changed constantly along the direction of water flow; the height of filler and mechanical ventilation had little influence on the composition of elements on the surface of CRI fillers, but had a certain influence on the proportion of elements.
\end{abstract}

Keywords: constructed rapid infiltration, domestic sewage, farmland irrigation, heavy metal, scanning electron microscope

\section{Introduction}

In the arid area of Northwest China, there is a lack of irrigation resources, non-point source pollution intensified by fertilization in farmland [1-3]. However, the target of sewage treatment in villages and towns

*e-mail: guozhenzhang126@126.com in this area is to reach the discharge standard, which not only increases the cost of sewage treatment, but also wastes the nitrogen and phosphorus in the sewage. Nitrogen and phosphorus are essential nutrients for crop growth.

Anaerobic baffled reactor (ABR) has the advantages of low operation cost, strong shock load resistance and good hydraulic conditions [4-7]. Using ABR as a pre-treatment process for agricultural irrigation and 
utilization of rural sewage can not only remove most of the organic pollutants and suspended solids in the sewage [8], but also fully retain the nitrogen and phosphorus in the sewage [9]. However, the COD, SS and heavy metals in the effluent of ABR are difficult to reach the irrigation water quality standards of all agricultural crops for a long time, so it is necessary to further treat the effluent of ABR. CRI has the advantages of small floor area, low operation cost and no sludge discharge $[10,11]$. By selecting suitable fillers and improving the operation conditions, the effluent can not only meet the irrigation water quality standards, but also fully retain the nitrogen and phosphorus in the sewage, so as to reduce the amount of chemical fertilizer, reduce the non-point source pollution caused by fertilization and improve the yield of crops.

At present, scholars at home and abroad have done a lot of research on strengthening CRI nitrogen and phosphorus removal [12-16] and microbial community structure in CRI [17, 18], but through improving CRI structure design, improving the removal effect of CRI on $\mathrm{COD}$ and $\mathrm{SS}$, and retaining nitrogen and phosphorus in sewage, so as to achieve the water quality standard of agricultural irrigation and the purpose of nitrogen and phosphorus conservation are rarely reported. In view of the above situation, three groups of CRI are proposed to be used for comparison to study the removal of pollutants and the change of surface characteristics of fillers by different CRI, so as to provide technical support for agricultural irrigation and utilization of rural sewage.

\section{Material and Methods}

\section{Experimental Device}

In this experiment, three groups of CRI were made of three identical plexiglass columns with an inner diameter of $0.14 \mathrm{~m}$. the height of CRI1 (left column) was $1.1 \mathrm{~m}$; the height of CRI2 (middle column) was $1.6 \mathrm{~m}$, and with two ventilators (fans); the height of CRI3 (right column) was $1.6 \mathrm{~m}$. the height of CRI1 from top to bottom was $0.1 \mathrm{~m}$ overflow height $+0.4 \mathrm{~m}$ clay ceramsite $+0.1 \mathrm{~m}$ gravel $+0.4 \mathrm{~m}$ coarse sand $+0.1 \mathrm{~m}$ gravel; the height of CRI2 from top to bottom was $0.1 \mathrm{~m}$ overflow height $+0.4 \mathrm{~m}$ clay ceramsite $+0.1 \mathrm{~m}$ ventilation layer $+0.4 \mathrm{~m}$ clay ceramsite $+0.1 \mathrm{~m}$ ventilation layer $+0.4 \mathrm{~m}$ coarse sand $+0.1 \mathrm{~m}$ gravel; the height of CRI3 from top to bottom was $0.1 \mathrm{~m}$ overflow height $+0.4 \mathrm{~m}$ clay ceramsite $+0.1 \mathrm{~m}$ gravel $+0.4 \mathrm{~m}$ clay ceramsite $+0.1 \mathrm{~m}$ gravel $+0.4 \mathrm{~m}$ coarse sand $+0.1 \mathrm{~m}$ gravel. three groups of CRI were respectively provided with overflow outlets at $0.05 \mathrm{~m}$ from the top of the column, CRI1 was provided with 4 filler sample ports at $0.3 \mathrm{~m}$ and $0.8 \mathrm{~m}$ from the top of the column, CRI2 and CRI3 were respectively provided with 4 filler sample ports at $0.3 \mathrm{~m}, 0.8 \mathrm{~m}$ and $1.3 \mathrm{~m}$ from the top of the column. The device was shown in Fig. 1.

\section{Experimental Water and Methods}

The domestic sewage treated by ABR was used as the experimental water. COD (chemical oxygen

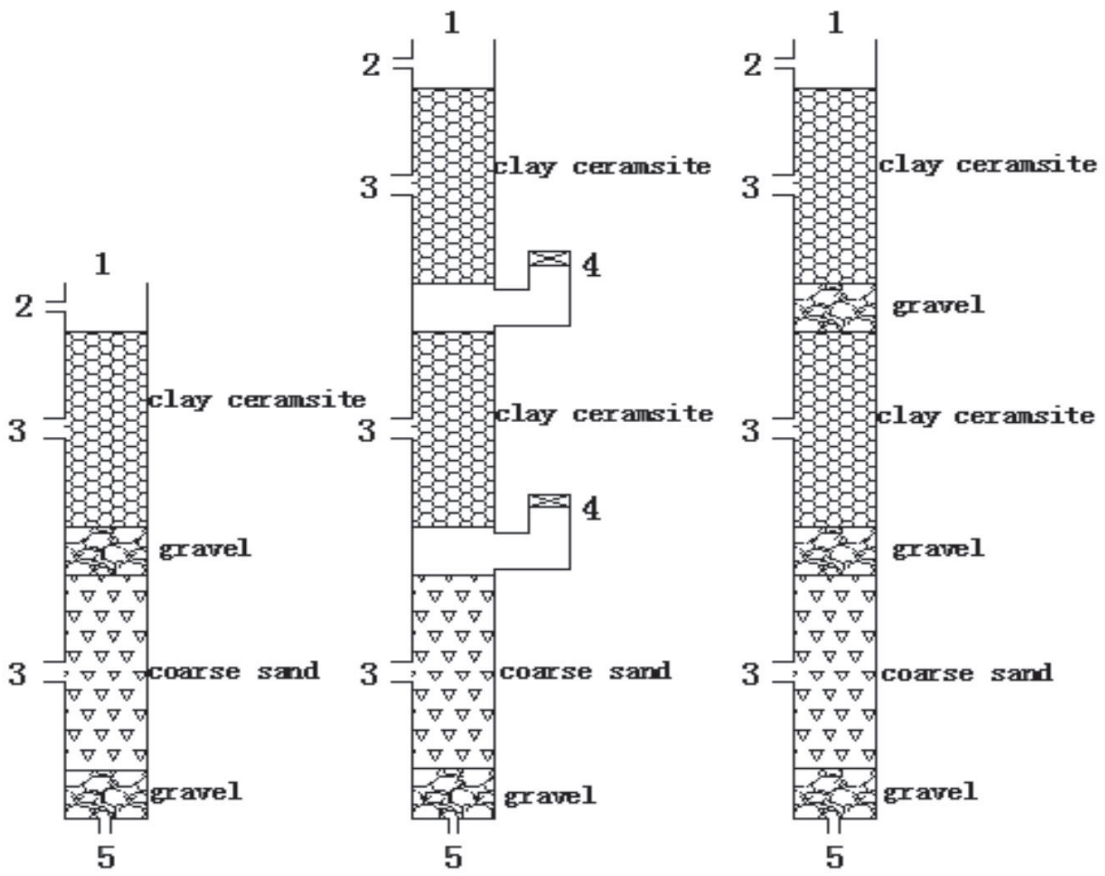

1、 water inlet 2、overflow port 3、filler sample port

4、fan 5、 water out let

Fig. 1. Schematic of CRI. 
demand) is $45.15 \sim 75.25 \mathrm{mg} / \mathrm{L}, \mathrm{SS}$ is $3.19 \sim 32.43 \mathrm{mg} / \mathrm{L}$, ammonia nitrogen is $29.12 \sim 41.30 \mathrm{mg} / \mathrm{L}$, total nitrogen is $29.89 \sim 42.50 \mathrm{mg} / \mathrm{L}$, total phosphorus is $2.45 \sim 3.76 \mathrm{mg} / \mathrm{L}$, $\mathrm{pH}$ is 7.87 8.08. The hydraulic load was $1 \mathrm{~m} / \mathrm{d}$, CRI1 and CRI3 were intermittent influent (influent for $2 \mathrm{~h}$, dry for 2 h), CRI2 was continuous influent. After the three groups of CRI operated stably, samples were taken from the three groups of CRI's water outlet and filler sample port for measurement.

\section{Analysis Items and Measurement Methods}

COD: potassium dichromate method; SS: gravimetric method; heavy metal: atomic absorption spectrophotometer method; filler surface morphology: thermal field emission scanning electron microscope; filler surface element composition and proportion: EDS (energy dispersive spectrometer) element analysis.

\section{Results and Discussion}

\section{Removal Effect of COD}

The removal effect of three groups of CRI on COD was shown in Fig. 2. It could be seen from Fig. 2 that the COD of influent water was 45.15-75.25 mg/L, exceeding the irrigation water quality standard of edible vegetables, melons and herbaceous fruits; the COD of effluent water of CRI1 was $16.56-42.14 \mathrm{mg} / \mathrm{L}$, with an average COD removal rate of $48.14 \%$; the COD of effluent water of CRI2 was $10.54-33.11 \mathrm{mg} / \mathrm{L}$, with an average COD removal rate of $55.12 \%$; the $\mathrm{COD}$ of effluent water of CRI3 was $10.54-43.65 \mathrm{mg} / \mathrm{L}$, with an average COD removal rate of $51.91 \%$. The average COD removal rate of three groups of CRI was: CRI2>CRI3>CRI1, which was mainly due to the lowest effective height of CRI1 (only $0.8 \mathrm{~m}$ ), therefore, the residence time of sewage in CRI1 was the shortest, and some organic pollutants in the sewage flowed out with the effluent before being filtered, intercepted, adsorbed and degraded by the

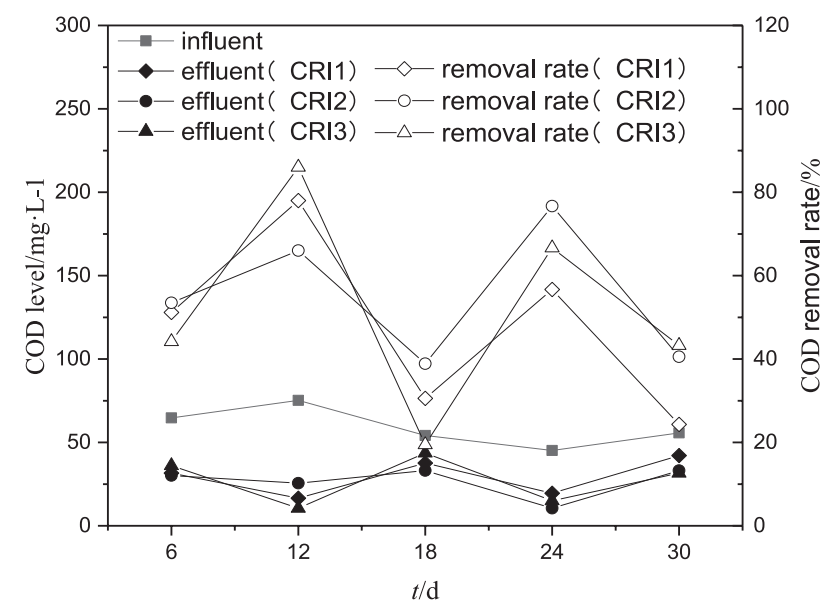

Fig. 2. The removal of COD by CRI. filler, so the average COD removal rate of CRI1 was the lowest; the effective height of CRI3 was higher $(1.2 \mathrm{~m})$. Therefore, the residence time of sewage in CRI3 was longer, and the organic pollutants in sewage could be fully filtered, intercepted, adsorbed and degraded by the filler, so the average COD removal rate of CRI3 was higher than CRI1; the effective height of CRI2 was the same as CRI3 (1.2 m), and it had two ventilation layers and two fans to supply air to the inside of the system, mechanical ventilation increased the dissolved oxygen in CRI2, resulting in the most aerobic microorganisms on the filler in CRI2, while the growth and propagation of aerobic microorganisms were faster, the amount of organic pollutants degraded by aerobic microorganisms was larger, so the average COD removal rate of CRI3 was the highest, which indicated that increasing the height of filler and the mechanical ventilation could improve the COD removal rate of CRI.

\section{Removal Effect of SS}

The removal effect of three groups of CRI on SS was shown in Fig. 3. It could be seen from Fig. 3 that the influent SS was 3.19-32.43 $\mathrm{mg} / \mathrm{L}$, exceeding the irrigation water quality standard of edible vegetables, melons and herbaceous fruits; the effluent SS of CRI1 was $0.76-3.43 \mathrm{mg} / \mathrm{L}$, with an average $\mathrm{SS}$ removal rate of $69.93 \%$; the effluent SS of CRI2 was $1.25-4.52 \mathrm{mg} / \mathrm{L}$, with an average SS removal rate of $64.53 \%$; the effluent SS of CRI3 was $0.03-3.67 \mathrm{mg} / \mathrm{L}$, with an average SS removal rate of $66.21 \%$. The average SS removal rate of the three groups of CRI was: CRI1 $>$ CRI3 $>$ CRI2, which may be because the influent water was the domestic sewage treated by ABR, the concentration of organic matter in the influent was lower, and the effective height of CRI3 was high $(1.2 \mathrm{~m})$, the microorganisms on the bottom filler got less nutrients, because of the lack of nutrients, some microorganisms were in the period of internal respiration or even decay, which leaded to the falling off of biofilm on the bottom filler, thus increasing the SS concentration in the effluent [19]; the

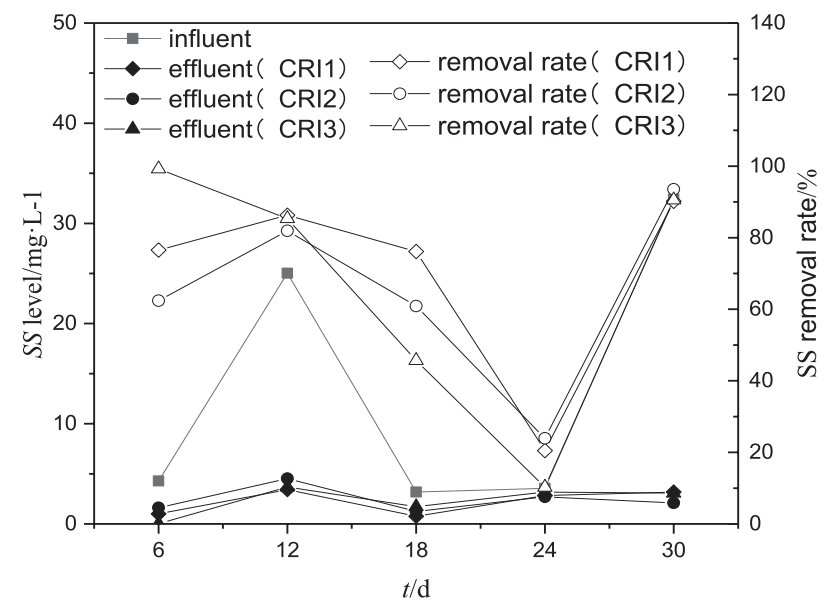

Fig. 3. The removal of SS by CRI. 
effective height of CRI2 was the same as that of CRI3 $(1.2 \mathrm{~m})$, mechanical ventilation increased the dissolved oxygen in CRI2, resulting in more removal of organic matter by microorganisms on the upper filler, and less nutrients could got by microorganisms on the bottom filler, so the biofilm on the bottom filler dropped more and the removal rate of SS was the lowest.

In general, the effluent SS of three groups of CRI reached the irrigation water quality standards of all crops.

\section{Removal Effect of Heavy Metals}

The removal effect of three groups of CRI on heavy metals was shown in Fig. 4 and Fig. 5. It could be seen from Fig. 4 and Fig. 5 that the concentrations of total mercury, total arsenic, cadmium and lead in the influent water were $0.00053 \mathrm{mg} / \mathrm{L}, 0.00080 \mathrm{mg} / \mathrm{L}$, $0.00030 \mathrm{mg} / \mathrm{L}$ and $0.00011 \mathrm{mg} / \mathrm{L}$, while chromium (hexavalent) (detection lower limit is $0.004 \mathrm{mg} / \mathrm{L}$ ) had not been detected, and the concentration of total mercury, total arsenic, cadmium, lead and chromium (hexavalent) in the influent water was relatively low. This was mainly because the influent water was the campus domestic sewage treated by ABR, while the campus domestic sewage had no industrial wastewater, and the concentration of several heavy metals in the campus domestic sewage was originally very low. After the ABR treatment, the concentration of several heavy metals in the sewage was lower. The concentrations of total mercury, total arsenic, cadmium and lead in CRI1 effluent were $0.00032 \mathrm{mg} / \mathrm{L}, 0.00079 \mathrm{mg} / \mathrm{L}$, $0.00027 \mathrm{mg} / \mathrm{L}$ and $0.00009 \mathrm{mg} / \mathrm{L}$, and the removal rates were $39.62 \%, 1.25 \%, 10.00 \%$ and $16.36 \%$, CRI1 had a certain removal effect on four heavy metals, mainly because the surface of the filler in CRI1 was rough and porous, and part of heavy metals in the sewage could be removed by adsorption and precipitation [2024]. CRI1 had different removal rates for four heavy metals, which was mainly due to the coexistence of multiple heavy metals in domestic sewage, multiple heavy metals would compete for the adsorption point on the filler, while the adsorption point on the filler was limited, and the number of specific adsorption points for various heavy metals on the filler was different [25].

The concentrations of total mercury, total arsenic, cadmium and lead in the effluent of CRI3 were $0.00021 \mathrm{mg} / \mathrm{L}, 0.00076 \mathrm{mg} / \mathrm{L}, 0.00028 \mathrm{mg} / \mathrm{L}$ and not detected (the detection lower limit was $0.00007 \mathrm{mg} / \mathrm{L}$ ), the removal rates were $60.38 \%, 5.00 \%, 6.67 \%$ and $100.00 \%$, the removal rates of total mercury, total arsenic and lead in CRI3 were $20.76 \%, 3.75 \%$ and $83.64 \%$ higher than those in CRI1, which was mainly due to the lower filler height of CRI1 (only $0.8 \mathrm{~m}$ ), therefore, there were less adsorption points for these heavy metals in CRI1, and the retention time of sewage in CRI1 was shorter, some heavy metals in sewage flowed out with the effluent before they were adsorbed and precipitated by the filler; the filler height of CRI3 was higher
$(1.2 \mathrm{~m})$, therefore, there were many adsorption sites for these heavy metals in CRI3, and the retention time of sewage in CRI3 was longer, some heavy metals in sewage could be fully adsorbed and precipitated by the filler. However, the removal rate of cadmium by CRI3 was 3.33\% lower than that of CRI1, which may be due to the fact that the amount of cadmium accumulated and retained by the filler in CRI3 in the early stage was more, leading to less adsorption points for cadmium in the later stage. The concentrations of total mercury, total arsenic, cadmium and lead in the effluent of CRI2 were $0.00021 \mathrm{mg} / \mathrm{L}, 0.00077 \mathrm{mg} / \mathrm{L}, 0.00027 \mathrm{mg} / \mathrm{L}$ and not detected (the detection lower limit was $0.00007 \mathrm{mg} / \mathrm{L}$ ), the removal rates were $60.38 \%, 3.75 \%$, $10.00 \%$ and $100.00 \%$, the difference between CRI2 and CRI3 was very small, which indicated that mechanical ventilation had little effect on the removal of heavy metals in domestic sewage.

Although the concentrations of the five heavy metals in the three groups of CRI in and out of the water were lower than the farmland irrigation water quality standard, due to the constant changes of the concentration of heavy metals in the domestic sewage and the fluctuation of ABR's removal rate of heavy

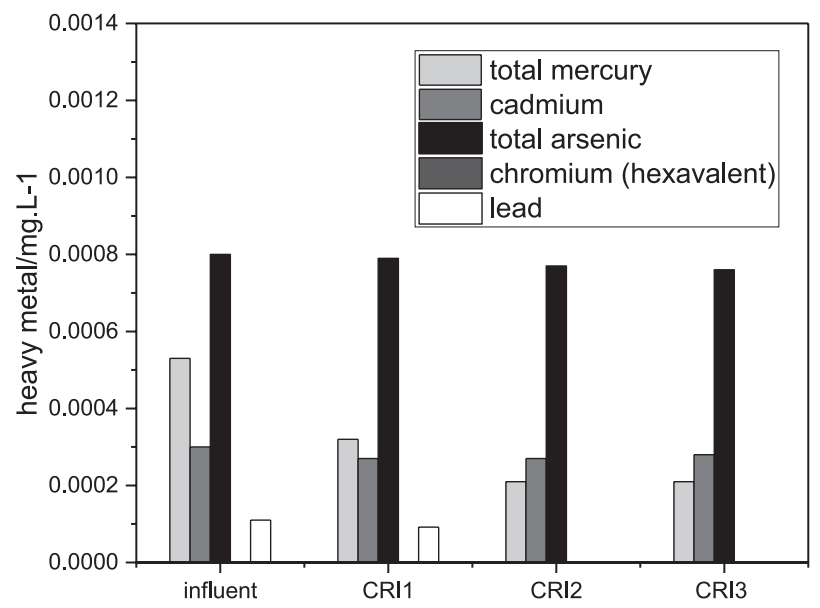

Fig. 4. The removal of heavy metals by CRI.

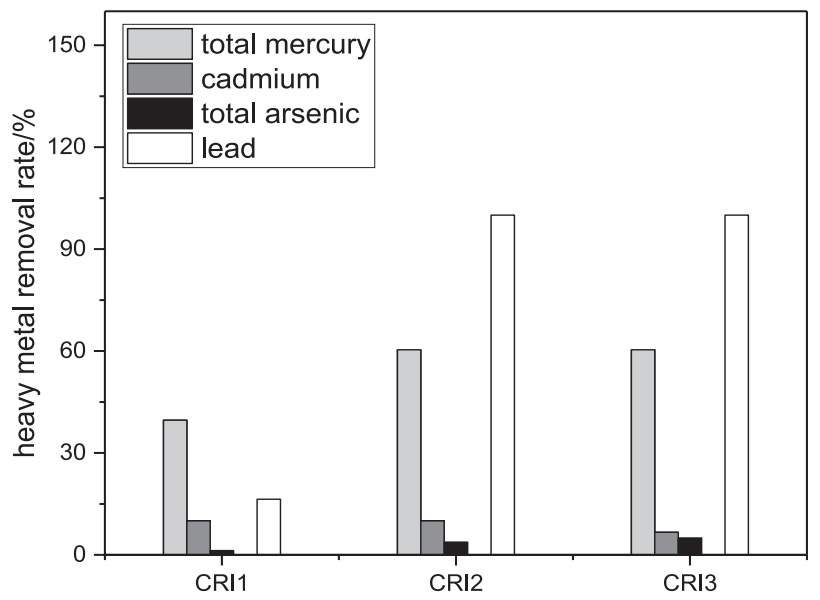

Fig. 5. The removal rate of heavy metals by CRI. 
metals, there may be a situation that the concentration of heavy metals in the effluent of ABR exceeds the farmland irrigation water quality standard during longterm operation. Moreover, heavy metals are easy to accumulate in soil and crops, so in the long run, it is necessary to further improve the removal rate of heavy metals in domestic sewage, so as to ensure that the heavy metals in treated domestic sewage can reach the standard of irrigation water quality for a long time.

\section{Surface Morphology of Filler}

The filler surface morphology of three groups of CRI before and after biofilm hanging was shown in Fig. 6. It could be seen from Fig. 6 that the surface of clay ceramsite and coarse sand was rough before the biofilm was hung, which was conducive to the fast attachment and growth of microorganisms on the surface of the filler, so as to formed a stable biofilm. After the three groups of CRI ran stably, at $0.3 \mathrm{~m}$ (refers to: $0.3 \mathrm{~m}$ from the top of CRI,the same below), the three groups of CRI fillers had formed a dense biofilm, which was mainly because this place was close to the CRI water inlet pipe, and the effect of reoxygenation was good, and microorganisms could obtain sufficient nutrients and oxygen, so the growth and reproduction of microorganisms on the fillers were relatively rapid; while there were some holes on the biofilm surface of the three groups of CRI fillers, which was conducive to the diffusion of nutrients in domestic sewage to the inside of biofilm, in order to ensure the growth and reproduction of the microorganisms in the biofilm, and the metabolites of microorganisms inside the biofilm were also discharged through the holes on the surface of the biofilm [26].

At $0.8 \mathrm{~m}$, the biofilm on the three groups of CRI fillers was less than $0.3 \mathrm{~m}$, which was mainly because it was far away from the CRI water inlet pipe and the microorganisms got less nutrients, so the growth and propagation speed of microorganisms on the fillers was slower than $0.3 \mathrm{~m}$. However, there were more biofilms on CRI2 filler than on CRI1 and CRI3, this was mainly because the reoxygenation effect of CRI1 and CRI3 was poor, and the oxygen obtained by microorganisms was less, while mechanical ventilation ensured that CRI2 had sufficient oxygen, so the growth and propagation speed of microorganisms on CRI2 filler was faster than that on CRI1 and CRI3.

At $1.3 \mathrm{~m}$, there were fewer biofilms on CRI2 and CRI3 fillers, which was mainly due to the fact that they were far away from the CRI water inlet pipe and the microorganisms got less nutrients, so the growth and propagation speed of microorganisms on the fillers were slower. However, there were fewer biofilms on CRI2 fillers than on CRI3, which was mainly due to the fact that the removal rate of organic pollutants by CRI2 was higher than that by CRI3 in the range of 0-1.3 $\mathrm{m}$, resulting in microorganisms on CRI2 filler at 1.3 m obtained less nutrients than CRI3, and mechanical ventilation provided sufficient oxygen for CRI2 at $1.3 \mathrm{~m}$, which made more microorganisms on CRI2 filler at $1.3 \mathrm{~m}$ appeared endogenous respiration and autolysis, resulting in more biofilm falling off on CRI2 filler at $1.3 \mathrm{~m}$.

\section{Element Composition and Proportion of Filler Surface}

The filler surface elements composition and proportion of three groups of CRI before and after biofilm hanging were shown in Fig. 7. It could be seen from Fig. 7 that the composition and proportion of surface elements of clay ceramsite and coarse sand were different before biofilm hanging. The surface elements of clay ceramsite mainly included: O (67.43\%), $\mathrm{C}(11.35 \%), \mathrm{Ca}(8.02 \%)$ and S (7.14\%), while the surface elements of coarse sand mainly included: O (74.33\%), $\mathrm{Ca}(10.90 \%)$ and $\mathrm{C}(8.75 \%)$ and as $(4.47 \%)$, which was mainly caused by the different structural composition and environment of clay ceramsite and coarse sand.

After the three groups of CRI operated stably, the composition of the surface elements of the three groups of CRI fillers was similar at $0.3 \mathrm{~m}, 0.8 \mathrm{~m}$ and $1.3 \mathrm{~m}$, but the proportion of the surface elements of the three groups of CRI fillers was different, which was mainly caused by the different design of the three groups of CRI devices, which resulted in the difference of their reoxygenation effect and the formation of different biofilms. Among them, the content of $\mathrm{O}$ was the highest, accounting for $58.42 \%-71.19 \%$ (CRI1), $51.42 \%-71.72 \%$ (CRI2) and 52.56\%-78.31\% (CRI3); the content of C was the second in most cases, accounting for $16.62 \%$ $26.41 \%$ (CRI1), $12.98 \%-21.93 \%$ (CRI2) and 11.63\%$30.29 \%$ (CRI3); the content of Ca was the third in most cases, accounting for 7.93\%-11.20\%(CRI1), $10.25 \%$ $23.40 \%$ (CRI2) and 4.18\%-17.24\% (CRI3), showed that the biofilm formed on the surface of three groups of CRI fillers was mainly composed of $\mathrm{O}, \mathrm{C}$ and $\mathrm{Ca}$, the sum of which was $95.74 \%-96.03 \%$ (CRI1), 94.95\%96.75\% (CRI2) and 94.24\%- 96.19\% (CRI3).

The surface elements of three groups of CRI fillers also included: $\mathrm{P}, \mathrm{S}, \mathrm{Cl}$, etc. Although the content of these elements was very small, they were indispensable for the growth and reproduction of microorganisms [27, 28]. In addition, the surface elements of three groups of CRI fillers also included: $\mathrm{As}, \mathrm{Cd}, \mathrm{Hg}$ and other heavy metals, which was mainly caused by the adsorption of a small amount of heavy metals in domestic sewage on the surface of three groups of CRI fillers [29, 30]. However, the proportion of several heavy metal elements on the surface of three groups of CRI fillers was relatively small, and some heavy metal elements were not detected. This was mainly because the concentration of several heavy metals in campus sewage was relatively low, and EDS element analysis could only select a part of the surface of fillers for analysis, and the part of the analyzed area on the surface of fillers may 
a) clay ceramsite (before biofilm hanging)

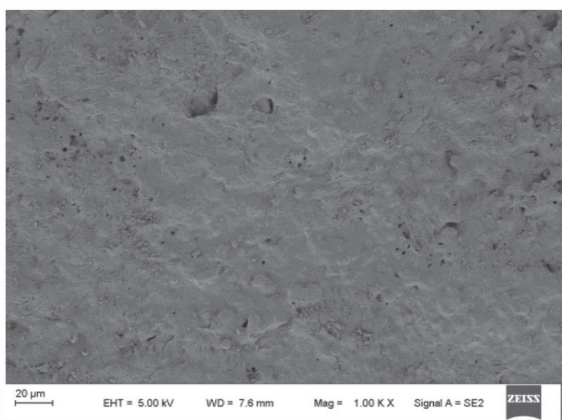

c) CRI1 $(0.3 \mathrm{~m})$

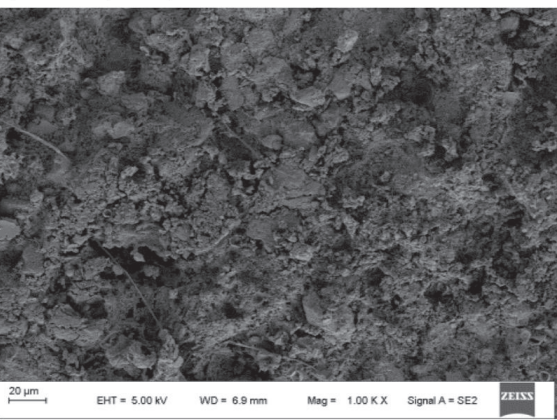

e) CRI2 $(0.3 \mathrm{~m})$

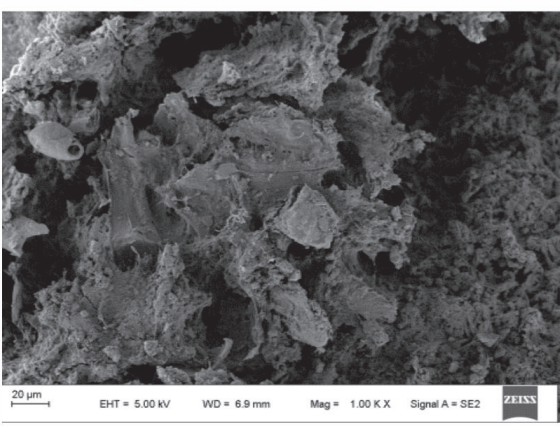

g) CRI2 (1.3 m)

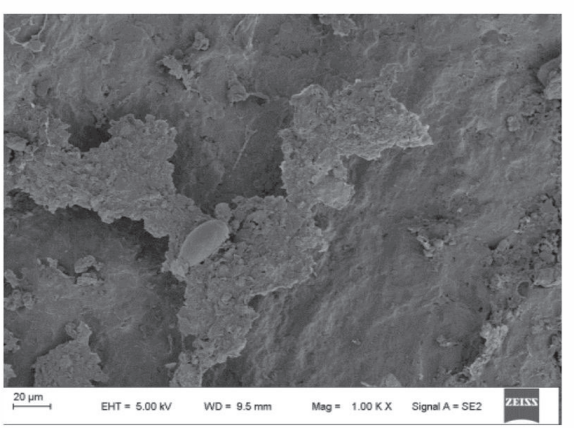

i) $\mathrm{CRI} 3(0.8 \mathrm{~m})$

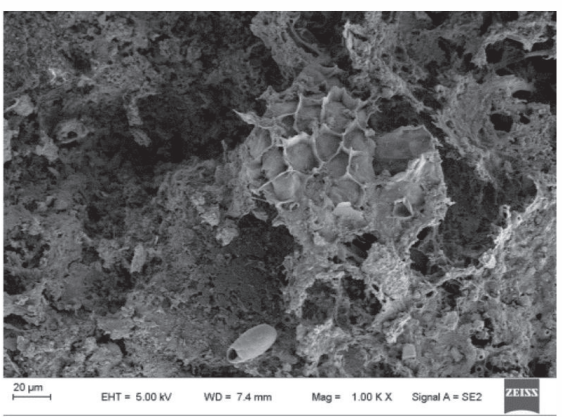

b) coarse sand(before biofilm hanging)

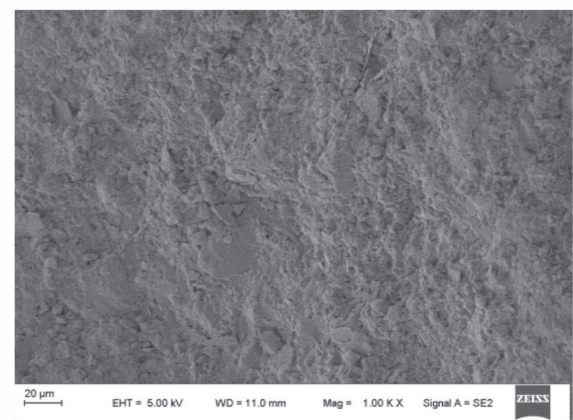

d) CRI1 $(0.8 \mathrm{~m})$

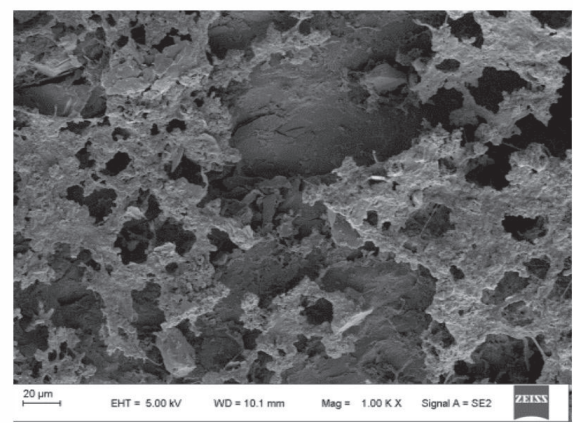

f) $\mathrm{CRI} 2(0.8 \mathrm{~m})$

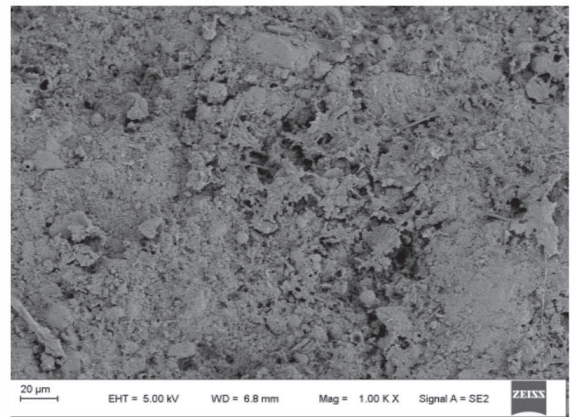

h) CRI3 $(0.3 \mathrm{~m})$

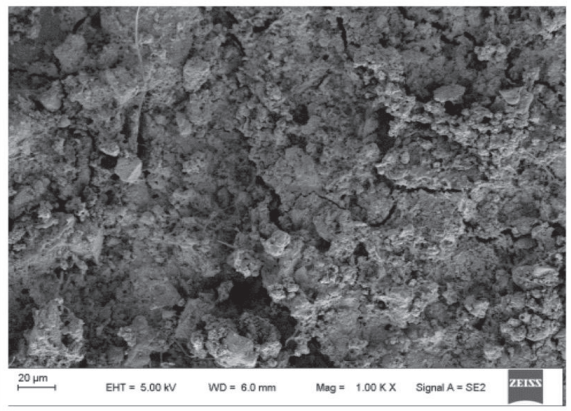

j) CRI3 (1.3 m)

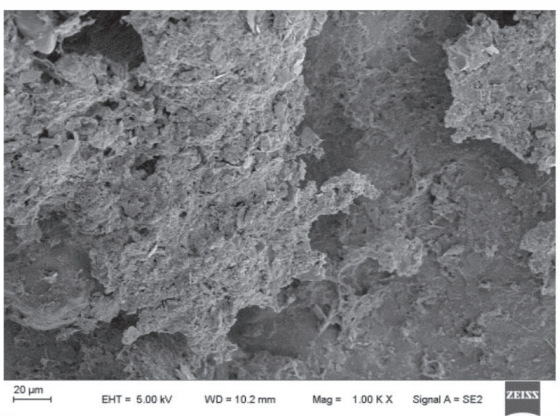

Fig. 6. The surface morphology of CRI fillers (1000 times). 
a) clay ceramsite (before biofilm hanging)

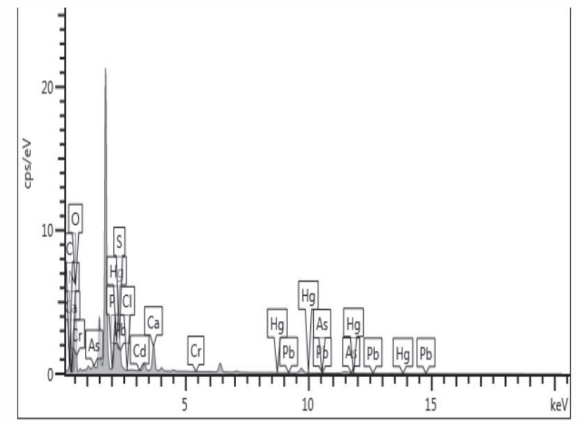

c) CRI1 $(0.3 \mathrm{~m})$

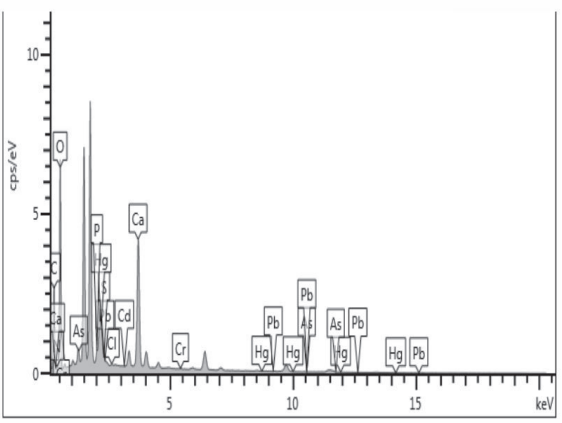

e) CRI2 $(0.3 \mathrm{~m})$

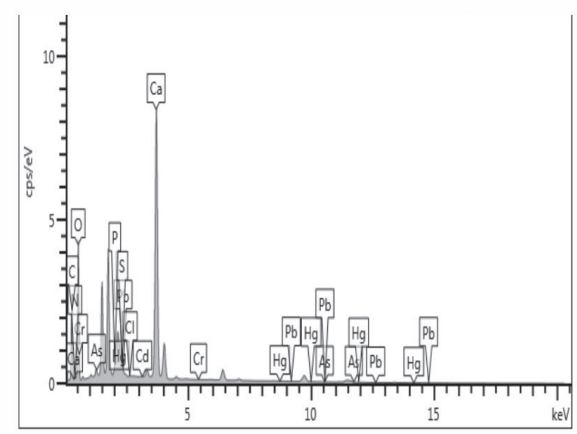

g) CRI2 (1.3 m)

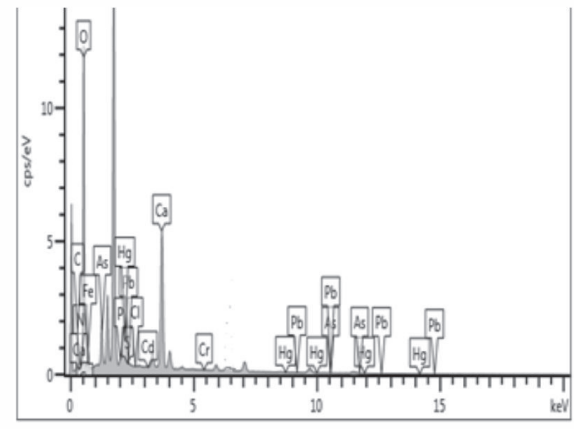

i) $\mathrm{CRI} 3(0.8 \mathrm{~m})$

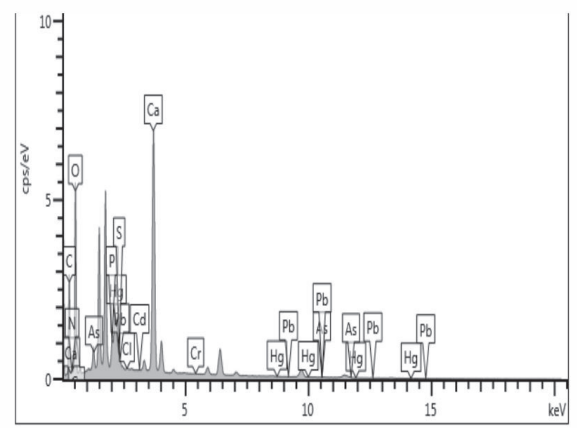

b) coarse sand(before biofilm hanging)

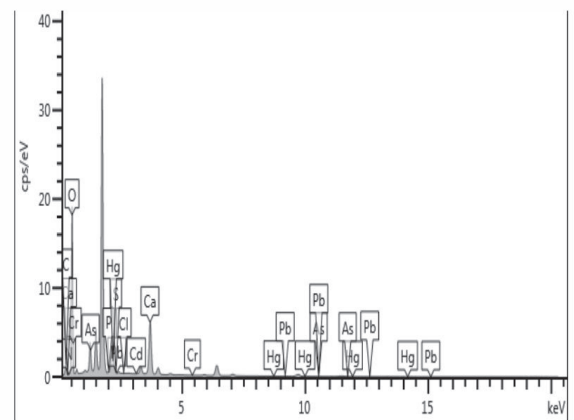

d) CRI1 $(0.8 \mathrm{~m})$

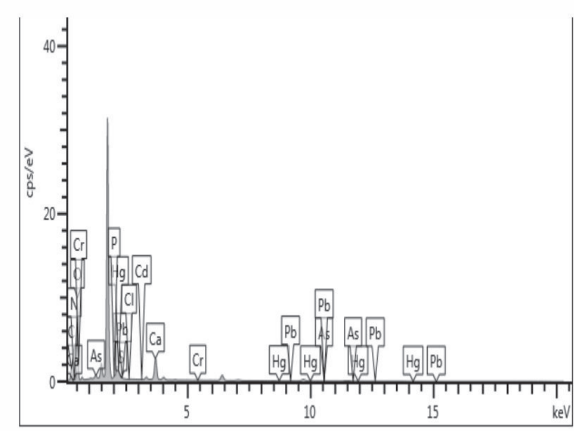

f) CRI2 (0.8 m)

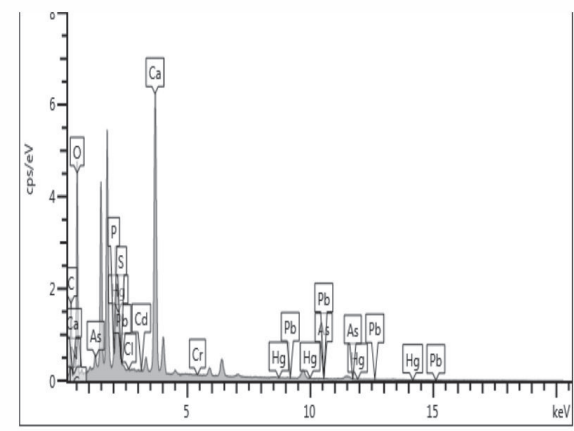

h) CRI3 $(0.3 \mathrm{~m})$

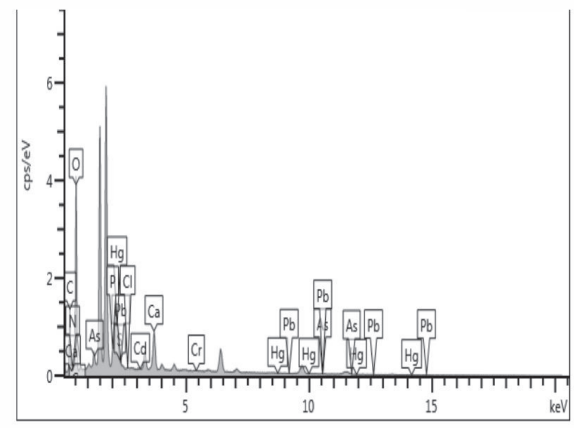

j) CRI3 $(1.3 \mathrm{~m})$

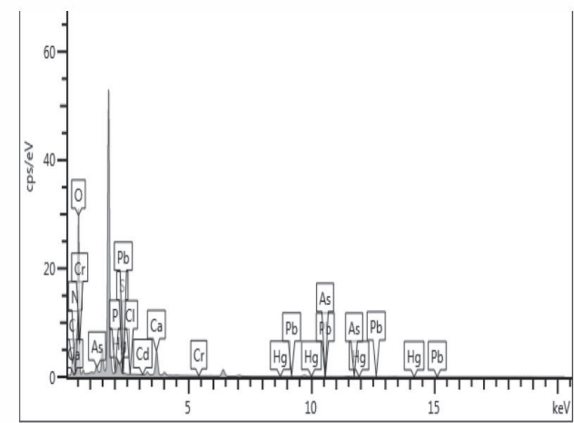

Fig. 7. The composition and proportion of elements on the surface of CRI fillers. 
a) clay ceramsite (before biofilm hanging)

\begin{tabular}{|c|c|c|}
\hline element & wt\% & wt\% Sigma \\
\hline $\mathrm{C}$ & 11.35 & 1.01 \\
\hline $\mathrm{O}$ & 67.43 & 0.85 \\
\hline $\mathrm{P}$ & 1.50 & 0.08 \\
\hline $\mathrm{S}$ & 7.14 & 0.13 \\
\hline $\mathrm{Cl}$ & 0.13 & 0.04 \\
\hline $\mathrm{Ca}$ & 8.02 & 0.14 \\
\hline $\mathrm{As}$ & 2.14 & 0.13 \\
\hline $\mathrm{Cd}$ & 0.73 & 0.12 \\
\hline $\mathrm{Hg}$ & 1.56 & 0.42 \\
\hline total: & 100.00 & \\
\hline & &
\end{tabular}

c) CRI1 $(0.3 \mathrm{~m})$

\begin{tabular}{|c|c|c|}
\hline element & wt\% & wt\% Sigma \\
\hline $\mathrm{C}$ & 26.41 & 0.45 \\
\hline $\mathrm{O}$ & 58.42 & 0.39 \\
\hline $\mathrm{P}$ & 1.12 & 0.04 \\
\hline $\mathrm{S}$ & 0.45 & 0.04 \\
\hline $\mathrm{Cl}$ & 0.08 & 0.02 \\
\hline $\mathrm{Ca}$ & 11.20 & 0.10 \\
\hline $\mathrm{As}$ & 1.94 & 0.07 \\
\hline $\mathrm{Cd}$ & 0.38 & 0.06 \\
\hline $\mathrm{Hg}$ & 0.00 & 0.00 \\
\hline total: & 100.00 & \\
\hline
\end{tabular}

e) CRI2 $(0.3 \mathrm{~m})$

\begin{tabular}{|c|c|c|}
\hline element & wt\% & wt\% Sigma \\
\hline $\mathrm{C}$ & 21.93 & 0.20 \\
\hline $\mathrm{O}$ & 51.42 & 0.17 \\
\hline $\mathrm{P}$ & 0.79 & 0.02 \\
\hline $\mathrm{S}$ & 0.64 & 0.02 \\
\hline $\mathrm{Cl}$ & 0.07 & 0.01 \\
\hline $\mathrm{Ca}$ & 23.40 & 0.09 \\
\hline $\mathrm{As}$ & 1.03 & 0.03 \\
\hline $\mathrm{Cd}$ & 0.30 & 0.03 \\
\hline $\mathrm{Hg}$ & 0.42 & 0.08 \\
\hline total: & 100.00 & \\
\hline
\end{tabular}

g) CRI2 $(1.3 \mathrm{~m})$

\begin{tabular}{|c|c|c|}
\hline element & wt\% & wt\% Sigma \\
\hline $\mathrm{C}$ & 12.98 & 0.49 \\
\hline $\mathrm{O}$ & 71.72 & 0.37 \\
\hline $\mathrm{P}$ & 0.78 & 0.04 \\
\hline $\mathrm{S}$ & 0.26 & 0.03 \\
\hline $\mathrm{Cl}$ & 0.00 & 0.00 \\
\hline $\mathrm{Ca}$ & 10.25 & 0.09 \\
\hline $\mathrm{As}$ & 3.68 & 0.10 \\
\hline $\mathrm{Cd}$ & 0.33 & 0.06 \\
\hline $\mathrm{Hg}$ & 0.00 & 0.00 \\
\hline total: & 100.00 & \\
\hline
\end{tabular}

i) CRI3 $(0.8 \mathrm{~m})$

\begin{tabular}{|c|c|c|}
\hline element & wt\% & wt\% Sigma \\
\hline $\mathrm{C}$ & 25.88 & 0.40 \\
\hline $\mathrm{O}$ & 52.56 & 0.33 \\
\hline $\mathrm{P}$ & 1.43 & 0.04 \\
\hline $\mathrm{S}$ & 0.73 & 0.04 \\
\hline $\mathrm{Cl}$ & 0.08 & 0.02 \\
\hline $\mathrm{Ca}$ & 17.24 & 0.13 \\
\hline $\mathrm{As}$ & 1.80 & 0.06 \\
\hline $\mathrm{Cd}$ & 0.29 & 0.05 \\
\hline $\mathrm{Hg}$ & 0.00 & 0.00 \\
\hline total: & 100.00 & \\
\hline
\end{tabular}

b) coarse sand(before biofilm hanging)

\begin{tabular}{|c|c|c|}
\hline element & wt\% & wt\% Sigma \\
\hline $\mathrm{C}$ & 8.75 & 0.48 \\
\hline $\mathrm{O}$ & 74.33 & 0.42 \\
\hline $\mathrm{P}$ & 0.84 & 0.04 \\
\hline $\mathrm{S}$ & 0.24 & 0.04 \\
\hline $\mathrm{Cl}$ & 0.00 & 0.00 \\
\hline $\mathrm{Ca}$ & 10.90 & 0.09 \\
\hline $\mathrm{As}$ & 4.47 & 0.11 \\
\hline $\mathrm{Cd}$ & 0.47 & 0.07 \\
\hline $\mathrm{Hg}$ & 0.00 & 0.00 \\
\hline total: & 100.00 & \\
\hline
\end{tabular}

d) CRI1 $(0.8 \mathrm{~m})$

\begin{tabular}{|c|c|c|}
\hline element & wt\% & wt\% Sigma \\
\hline $\mathrm{C}$ & 16.62 & 0.51 \\
\hline $\mathrm{O}$ & 71.19 & 0.45 \\
\hline $\mathrm{P}$ & 1.83 & 0.05 \\
\hline $\mathrm{S}$ & 0.75 & 0.04 \\
\hline $\mathrm{Cl}$ & 0.00 & 0.00 \\
\hline $\mathrm{Ca}$ & 7.93 & 0.08 \\
\hline $\mathrm{As}$ & 1.38 & 0.08 \\
\hline $\mathrm{Cd}$ & 0.30 & 0.07 \\
\hline $\mathrm{Hg}$ & 0.00 & 0.00 \\
\hline total: & 100.00 & \\
\hline
\end{tabular}

f) CRI2 $(0.8 \mathrm{~m})$

\begin{tabular}{|c|c|c|}
\hline element & wt\% & wt\% Sigma \\
\hline $\mathrm{C}$ & 20.03 & 0.56 \\
\hline $\mathrm{O}$ & 56.61 & 0.46 \\
\hline $\mathrm{P}$ & 0.90 & 0.06 \\
\hline $\mathrm{S}$ & 0.45 & 0.05 \\
\hline $\mathrm{Cl}$ & 0.00 & 0.00 \\
\hline $\mathrm{Ca}$ & 20.03 & 0.20 \\
\hline $\mathrm{As}$ & 1.65 & 0.09 \\
\hline $\mathrm{Cd}$ & 0.34 & 0.08 \\
\hline $\mathrm{Hg}$ & 0.00 & 0.00 \\
\hline total: & 100.00 & \\
\hline
\end{tabular}

h) CRI3 (0.3 m)

\begin{tabular}{|c|c|c|}
\hline element & wt\% & wt\% Sigma \\
\hline $\mathrm{C}$ & 30.29 & 0.72 \\
\hline $\mathrm{O}$ & 59.77 & 0.65 \\
\hline $\mathrm{P}$ & 2.00 & 0.08 \\
\hline $\mathrm{S}$ & 0.68 & 0.07 \\
\hline $\mathrm{Cl}$ & 0.11 & 0.04 \\
\hline $\mathrm{Ca}$ & 4.18 & 0.09 \\
\hline $\mathrm{As}$ & 2.42 & 0.12 \\
\hline $\mathrm{Cd}$ & 0.55 & 0.11 \\
\hline $\mathrm{Hg}$ & 0.00 & 0.00 \\
\hline total: & 100.00 & \\
\hline
\end{tabular}

j) $\mathrm{CRI} 3(1.3 \mathrm{~m})$

\begin{tabular}{|c|c|c|}
\hline element & wt\% & wt\% Sigma \\
\hline $\mathrm{C}$ & 11.63 & 0.36 \\
\hline $\mathrm{O}$ & 78.31 & 0.34 \\
\hline $\mathrm{P}$ & 0.99 & 0.03 \\
\hline $\mathrm{S}$ & 0.30 & 0.03 \\
\hline $\mathrm{Cl}$ & 0.08 & 0.02 \\
\hline $\mathrm{Ca}$ & 6.25 & 0.05 \\
\hline $\mathrm{As}$ & 1.72 & 0.06 \\
\hline $\mathrm{Cd}$ & 0.30 & 0.04 \\
\hline $\mathrm{Hg}$ & 0.41 & 0.13 \\
\hline total: & 100.00 & \\
\hline
\end{tabular}

Fig. 7. Continued. 
just not contain these undetected heavy metal elements, but other areas inside and on the surface of the filler may contain these undetected heavy metals.

\section{Conclusions}

1. Increasing the filler height and mechanical ventilation could promote the removal of COD from ABR effluent by CRI, but inhibit the removal of SS from ABR effluent by CRI; increasing the filler height could promote the removal of most heavy metals from ABR effluent by CRI, while mechanical ventilation had little effect on the removal of heavy metals from ABR effluent by CRI.

2. The biofilm on three groups of CRI fillers decreased gradually along the direction of water flow. Mechanical ventilation increased the biofilm on CRI fillers at $0.8 \mathrm{~m}$, but decreased the biofilm on CRI fillers at $1.3 \mathrm{~m}$.

3. The main elements on the surface of three groups of CRI fillers were $\mathrm{O}, \mathrm{C}$ and $\mathrm{Ca}$, in addition, they also included: $\mathrm{P}, \mathrm{S}, \mathrm{Cl}, \mathrm{As}, \mathrm{Cd}$ and $\mathrm{Hg}$, etc.; the composition of elements on the surface of three groups of CRI fillers changed little along the direction of water flow, but the proportion of elements changed constantly along the direction of water flow; the filler height and mechanical ventilation had little influence on the composition of elements on the surface of CRI fillers, but had some influence on the proportion of elements.

\section{Funding}

This research was funded by the National Natural Science Foundation of China (Grant No. 51768031) and the Key Research and Development Program in Gansu Province (Grant No. 17YF1NA056).

\section{Acknowledgements}

Thanks to Prof. Guozhen Zhang and Prof. Fuping $\mathrm{Wu}$ for providing experimental platform and guidance for the formulation of the experimental scheme and the completion of the experiment; to Wenwen Yan for the help in the sample testing process; and to Tianhong Zhou for the help in the writing process of the paper.

\section{Conflict of Interest}

The authors declare no conflict of interest.

\section{References}

1. NAN J.Q., WANG J.L., TAO G.T., XIAO J.F., LIU Z.D., NING D.F., QIN A.Z. Study on the matching pattern of agricultural water and soil resources in arid areas of Northwest China, Journal of Irrigation and Drainage, 34 (5), 41, 2015.

2. ZHU J.G., ZHANG X.J., LIU X., GUO X.Y. Removal effect of ecological ditch-wetland system on nitrogen and phosphorus from farmland drainage. Journal of Agricultural Environmental Science, 38 (2), 405, 2019.

3. ZHONG Z.M., HUANG Y.B., LI Y.C., HUANG X.S., CHEN Z.D., FENG D.Q. Present situation of agricultural non-point source pollution in China and application of herbaceous plants in pollution control. Grassland Science, 34 (2), 428, 2017.

4. PIRSAHEB M., MOHAMADI S., RAHMATABADI S., HOSSINI H., MOTTERAN F. Simultaneous wastewater treatment and biogas production using integrated anaerobic baffled reactor granular activated carbon from baker's yeast wastewater. Environmental Technology, 39 (21), 2724, 2018.

5. SAYEDIN F., KERMANSHAHI-POUR A., He Q.S. Anaerobic digestion of thin stillage of corn ethanol plant in a novel anaerobic baffled reactor. Waste Management, 78, 541, 2018.

6. JIANG Y.R., QIN Y.L., YU F.M., LI H., LIU K.H. Is $\mathrm{COD} / \mathrm{SO}_{4}^{2-}$ ratio responsible for metabolic phaseseparation shift in anaerobic baffled reactor treating sulfate-laden wastewater? International Biodeterioration \& Biodegradation, 126, 37, 2018.

7. JIANG H., NIE H., DING J.T., STINNER W., SUN K.X., ZHOU H.J. The startup performance and microbial distribution of an anaerobic baffled reactor (ABR) treating medium-strength synthetic industrial wastewater. Journal of Environmental Science and Health, 53 (1), 46, 2018.

8. FUJIHIRA T., SEO S., YAMAGUCHI T., HATAMOTO M., TANIKAWA D. High-rate anaerobic treatment system for solid/lipid-rich wastewater using anaerobic baffled reactor with scum recovery. Bioresource Technology, 263, 145, 2018.

9. AL SMADI B.M., AL-HAYEK W., ABU HAJAR H.A. Treatment of amman slaughterhouse wastewater by anaerobic baffled reactor. International Journal of Civil Engineering, 17 (9), 1445, 2019.

10. WANG D.B., ZHANG Z.Y., LI X.M., ZHENG W., YANG Q., DING Y., ZENG T.J. A full-scale treatment of freeway toll-gate domestic sewage using ecology filter integrated constructed rapid infiltration. Ecological Engineering, 36 (6), 827, 2010.

11. XU W.L., ZHANG J.Q., LIU Y. Organic matter degradation kinetics and filter layer height calculation model in constructed rapid infiltration system. Fresenius Environmental Bulletin, 20 (11), 1487, 2011.

12. WANG M.C., ZHANG H.Z. Chemical Oxygen Demand and Ammonia Nitrogen Removal in a Non-saturated Layer of a Strengthened Constructed Rapid Infiltration System. Water, Air, \& Soil Pollution, 228 (11), 440, 2017.

13. ZHANG X.L., GUO L., HUANG H.L., JIANG Y.H., LI M., LENG Y.J. Removal of phosphorus by the core-shell bioceramic/Zn-layered double hydroxides (LDHs) composites for municipal wastewater treatment in constructed rapid infiltration system. Water Research, 96 (3), 280, 2016.

14. FANG Q.L., XU W.L., YAN Z.J., QIAN L. Effect of Potassium Chlorate on the Treatment of Domestic Sewage by Achieving Shortcut Nitrification in a Constructed Rapid Infiltration System. International Journal of Environmental Research and Public Health, 15 (4), 670, 2018.

15. FANG Q.L., XU W.L, XIA G.H., PAN Z.C. Effect of $\mathrm{C} / \mathrm{N}$ Ratio on the Removal of Nitrogen and Microbial 
Characteristics in the Water Saturated Denitrifying Section of a Two-Stage Constructed Rapid Infiltration System. International Journal of Environmental Research and Public Health, 15 (7), 469, 2018.

16. CHEN J., LU Y.X., ZHANG J.Q., WANG R., HUANG W. Impact of starvation on the nitrification performance of constructed rapid infiltration systems. Acta Scientiae Circumstantiae, 38 (12), 4703, 2018.

17. CHENG H.Y., XIA G.H., LI M., QIAN L., XU W.L., LIU Y.X. Performance and microbial community analysis of a constructed rapid infiltration system at different depths. Pol. J. Environ. Stud., 29 (5), 3085, 2020.

18. JIANG X., MA M.C., LI J., LU A.H. Analysis of microbial molecular ecology techniques in constructed Rapid Infiltration system. Journal of Earth Science, 22 (5), 669, 2011.

19. ZHANG X.R., LI H.B., LI Y.H., GUO F., YANG Z.X., BAI J.N. Do wet-dry ratio and Fe-Mn system affect oxidation-reduction potential nonlinearly in the subsurface wastewater infiltration systems? International Journal of Environmental Research and Public Health, 15 (12), 2790, 2018.

20. WEI L.L., LI Y., NOGUERA D.R., ZHAO N.B., SONG Y., DING J., ZHAO Q.L. Adsorption of $\mathrm{Cu}^{2+}$ and $\mathrm{Zn}^{2+}$ by extracellular polymeric substances (EPS) in different sludges. Effect of EPS fractional polarity on binding mechanism. Journal of Hazardous Materials, 321, 473, 2017.

21. XUE S., ZHAO Q.L., WEI L.L., HUI X.J., MA X.P., LIN Y.Z. Fluorescence spectroscopic studies of the effect of granular activated carbon adsorption on structural properties of dissolved organic matter fractions. Frontiers of Environmental Science \& Engineering, 6 (6), 784, 2012.

22. LIU W., ZHANG J.S., JIN Y.J., ZHAO X., CAI Z.Q. Adsorption of $\mathrm{Pb}(\mathrm{II}), \mathrm{Cd}(\mathrm{II})$ and $\mathrm{Zn}$ (II) by extracellular polymeric substances extracted fromaerobic granular sludge. Efficiency of protein. Journal of Environmental Chemical Engineering, 3 (2), 1223, 2015.
23. MIAO L.Z., WANG C., HOU J., WANG P.F., AO Y.H., LI Y. Contributions of different fractions of extracellular polymeric substances from waste-activatedsludge to $\mathrm{Cu}$ (II) biosorption. Desalination and Water Treatment, 57 (45), 21405, 2016.

24. ZENG T.T., RENE E.R., ZHANG S.Q., LENS P.N.L. Removal of selenate and cadmium by anaerobic granular sludge: EPS characterization and microbial community analysis. Process Safety and Environmental Protection, 126, 150, 2019.

25. JIANG M., HU X.W., NGUYEN D.T., LI J.Y., YUE Y., NING P. Adsorption of $\mathrm{Pb}^{2+}, \mathrm{Cu}^{2+}, \mathrm{Cd}^{2+}$ by aerobic granular sludge. Water Treatment Technology, 39 (2), 53, 2013.

26. WANG N., PENG D.C. Study on the regulation mechanism of anaerobic granular sludge based on performance improvement. Water Treatment Technology, 44 (1), 21, 2018.

27. KUSCUO S., SPONZAD T. Performance of anaerobic baffled reactor. ABR treating synthetic wastewater containing p-nitrophenol. Enzyme \& Microbial Technology, 36 (7), 888, 2005.

28. CHEN Q., WANG Y.L., ZHAO L., ZHANG P.Y. Synchronized start-up of ABR-MABR coupling process for livestock and poultry wastewater treatment. Environmental Science Research, 30 (2), 298, 2017.

29. GAO C.G., ZHANG X.L., YUAN Y., LEI Y., GAO J.T., ZHAO S.J., HE C.Y., DENG L.C. Removal of hexavalent chromium ions by core-shell sand/Mg-layer double hydroxides (LDHs) in constructed rapid infiltration system. Ecotoxicology and Environmental Safety, 166 (12), 285, 2018.

30. ZHANG X.L., LEI Y., YUAN Y., GAO J.T., JIANG Y.H., XU Z.Y., ZHAO S.J. Enhanced removal performance of $\mathrm{Cr}(\mathrm{VI})$ by the core-shell zeolites/layered double hydroxides (LDHs) synthesized from different metal compounds in constructed rapid infiltration systems. Environmental Science and Pollution Research International, 25 (10), 9759, 2018. 